\title{
Toward Professionalization: Fund Raising Norms and Their Implications for Practice
}

Received (in revised form): March 5, 2003

\section{Timothy C. Caboni}

Timothy C. Caboni is a Lecturer in Public Policy and Higher Education, and director of the institutional advancement program in the Department of Leadership, Policy and Organizations at Peabody College, Vanderbilt University.

\section{Abstract}

This article outlines the core traits of professions and discusses the extent to which fund raising possesses these traits. Three inviolable and six admonitory normative patterns of fund-raising behavior are described and their implications for the practice of fund raising are discussed. This article reexamines the fund-raising profession in comparison with the markers of true professions as suggested in the sociological literature. First, the core traits of professions and their relationship to fund raising is examined. Second, professional self-regulation is discussed. Third, the informal norms that fund raisers use to self-regulate are described. Finally, the importance of these norms to the profession and their use for practitioners is outlined.

Author's Contact Address:

Dr. Timothy C. Caboni

Dept of Leadership, Policy \& Organizations

Peabody College, Vanderbilt University

Box 514, GPC

Nashville, TN, 37203, USA

Tel: +1 6153432493

Fax: +16153437377

Email: tim.caboni@vanderbilt.edu
Keywords:

Fund raising, professional characteristics, professionalism, professional etbics, fund-raising norms

\section{Sociological Inquiry and Professions}

Carr-Saunders and Wilson outlined the historical progression of professions in Great Britain over two centuries. ${ }^{1}$ Within their work emerges the notion that a profession is defined by its members having a set of specialized skills, charging set fees, having a professional association and a code of ethics. Since the 1933 study by Carr-Saunders and Wilson, the study of professions has remained an important part of sociological inquiry.

There are certain attributes by which one can determine if an occupation is a profession. Greenwood describes five attributes that are possessed by an ideal profession. ${ }^{2}$ First, it will have a body of systematic theory on which it draws. This body of knowledge requires an extensive period of training. Second, its professional authority is recognized by the profession's clients. In the client/professional relationship, the client believes that what the professional judges to be appropriate 
should not be questioned. Professionals, because of their extensive training (and because the client does not possess that training), are perceived as knowing what is best for the client. Third, the community at large agrees that the profession has this authority. Fourth, a profession will have a code of ethics that is used by members of a profession to self-regulate their behavior. Finally, a profession will have a formal association to which its members belong.

Greenwood also suggests that professions should be seen as being distributed along a continuum of professionalism. Additionally, Greenwood asserts that, "the crucial distinction between professions and nonprofessions is this: the skills that characterize a profession flow from and are supported by a fund of knowledge that has been organized into an internally consistent system called a body of theory." 3

Theories of professions frequently focus on one of two main characteristics; first, is it knowledge-based? And second, does it establish a monopoly in the market for its services? Parsons claimed that professions serve an altruistic, social function: "a fullfledged profession must have some institutional means of making sure that such [professional] competence will be put to socially responsible uses." " This view was attacked by Johnson and others who emphasized the power of professions. ${ }^{5}$ Instead of altruism, some suggest that professions aim to create "market shelters" "6 and market monopolies. ${ }^{7}$ From this point of view, it is important for a profession to seek to license its particular professional practices. $^{8}$

In contrast to approaches focusing on professional knowledge or market monopolies, Abbott claims that the professions have to be seen as a system. ${ }^{9}$
The system is based around work and consists of professions and their links to particular tasks. Abbott calls the link between a profession and its tasks "jurisdiction." The professions compete with one another for control of particular tasks. "In claiming jurisdiction, a profession asks society to recognize its cognitive structure through exclusive rights." ${ }^{10}$ Knowledge is one means in professional competition; it is the "currency of competition."11

Brint suggests that professions now more frequently define themselves in terms of the skills and knowledge possessed by members of the profession. ${ }^{12}$ Rarely do members of a profession turn to the social importance of their work as a justification of social status. However, because of the lack of a well-developed body of knowledge, for fund raising to claim professional status it must look to the other characteristics of professions that it might possess.

\section{Professionalization of Fund Raising and Professional Traits}

Professions possess a number of characteristics and traits. These include: an extensive period of training and socialization, the possession of a systematic body of theory, the formation of professional associations, and the existence of a code of conduct. Additionally, members of a profession adhere to an ideal of service, and conduct their work with autonomy from external review. ${ }^{13}$ The degree to which fund raising meets each of these criteria is discussed below.

\section{Extensive Period of Training}

While there is no certification required for practicing as a fund raiser, there has been 
a recent proliferation of programs designed to prepare individuals who choose fund raising as a career. This is in addition to the certificate offered by the Association of Fundraising Professionals (AFP) to individuals who have been practicing in the field for over five years and who have met the necessary criteria. Carbone reports that many practicing fund raisers view this certificate with disdain. Others, however, view the certificate as helpful when entering the profession. $^{14}$

Fund raisers, according to practitioners in the field, possess no specialized knowledge for doing their jobs. Carbone also found that while fund raisers believe that there is a codified body of knowledge, most were of the opinion that these principles were best learned on the job, rather than through formal educational instruction, as done in most true professions. ${ }^{15}$ However, there are informal paths through which individuals progress through the fund-raising ranks. Entry level fund raisers rarely have contact with an institution's top donors. Frequently they spend much of their time designing directmail appeals in annual fund offices, or doing research on individuals who have the capacity to make large gifts.

After some time, an individual may rise to the level of manager of an annual fund or may shift to major gifts as a development officer. Even in these positions, at some institutions fund raisers rarely interact with prospects who have been targeted for the largest gifts. At others, all major gift officers have access to the largest prospects. This is evidence of on-the-job training that may last for many years.

Additionally, because there is a nascent group of programs in fund raising beginning to appear at colleges and universities across the country, this is not an area in which additional research is needed to argue for the professionalization of the field.

\section{Formation of Professional Associations}

Fund raisers have two primary professional organizations that serve their professional needs. For fund raisers engaged in fund raising primarily for colleges and universities (although private secondary schools are members) the Council for Advancement and Support of Education (CASE) serves as these individuals' primary professional organization. An umbrella group, CASE counts among its members individuals who are also responsible for alumni relations, public relations, publications, government relations, and enrollment management. CASE was formed in 1974 through a merger of the American Alumni Council (AAC, founded in 1913) and the American College Public Relations Association (ACPRA, founded in 1917).

The Association of Fundraising Professionals (AFP, founded as the National Society of Fund-Raising Executives in 1960) is a national organization whose membership contains fund raisers for educational institutions as well as those fund raisers who work for social service organizations and other notfor-profit organizations.

A number of secondary professional organizations exist to support fund raisers. These include the Association of Lutheran Development Executives (ALDE), Association for Healthcare Philanthropy (AHP), Association of Professional Researchers for Advancement (APRA), and others. 
The existence of these professional associations is another marker of professionalization for fund raising. For the purposes of this article, attention will be concentrated on AFP and CASE.

\section{Existence of a Code of Conduct}

Both AFP and CASE have adopted codes of conduct that apply to their members. CASE adopted the Donor Bill of Rights in 1982. AFP's Code of Ethical Principals was adopted in 1991 and the Principles for Practice were added in 1992. The existence of these codes is an additional marker of professionalism possessed by the field. It should be noted that these are of relatively recent origin.

\section{Systematic Body of Theory and Mastery of Knowledge}

One of the challenges for fund raising as it progresses toward professional status is the lack of inquiry into the fund-raising function within the college and university environment. One of the markers of professionalism is the existence of a knowledge base in which practitioners are well versed. Typically, this knowledge is mastered through an extended period of training.

Carbone writes that fund raisers themselves report that the knowledge they use in doing their duties as development officers is primarily general knowledge that is possessed by anyone. ${ }^{16}$ They also believe that such knowledge is best learned on the job rather than in formal education.

Rowland states that "the systematic study of institutional advancement, employing social science and managementbased research methodologies, is of comparatively recent origin." "17 Kelly notes that of the studies that appear in
Rowland's work, "there are few, if any studies on basic research or theory building." 18 The research that does exist is limited, fragmented, and of marginal quality. ${ }^{19}$ Additionally, the majority of articles focus on the motivators that exist for donors of a particular institution. ${ }^{20}$ With vast differences among higher education institutions, a broader inquiry is needed across the spectrum of colleges and universities. Payton suggests that "a lot of people don't want to be bothered with fund-raising, don't like it, find it distasteful and don't want to be involved with it at all.",21

This lack of a well-developed body of knowledge poses an important challenge to those interested in fund raising moving toward professionalization. As discussed previously, Brint suggests that technical knowledge is becoming the most important marker that differentiates professions from occupations. ${ }^{22}$ If this is the case, fund raising as a profession must begin to encourage scholarly inquiry into fund raising for colleges and universities. CASE has addressed this need through the annual award program for outstanding dissertations focused on fund raising in higher education. The journal in which this article appears is another vehicle through which the professional organization may encourage scholarly inquiry. Other steps that might be of value to increasing the knowledge base include: encouraging current scholars to pursue research on issues of fund raising within higher education through research grants; increasing the number of faculty members presenting research on fund raising at annual professional conferences; and supporting emerging programs designed to prepare scholars whose primary research focus will be fund raising 
within the context of postsecondary education.

Because the fund-raising profession lacks a substantial knowledge base, focus must be placed upon the professional characteristic of the ideal of service if fund raising is to lay claim to status as a profession.

\section{Ideal of Service and Fund Raising}

Goode suggests that members of a profession must base their individual decisions on what will serve the needs and protect the welfare of their clients. ${ }^{23}$ If viewed through this lens, the fund-raising profession has two separate clients for whom it is responsible: the institution and the donor.

Professional fund raisers are responsible for the welfare of their institutional clients. Development officers are charged with providing necessary capital for the operations of their institutions and for raising money to create endowed funds to provide support for specific projects, programs, scholarships, and professorships in perpetuity. Rosso suggests that development officers should be hired for their ability to clearly articulate the mission and values of the organization, and because of a personal commitment to the institutional mission. ${ }^{24}$ This commitment to the college or university mission separates professional fund raisers from salespeople. The fund raiser should believe strongly in the institution and its goals, and view fund raising as a way of advancing the institution. Along with this responsibility comes the potential for causing great harm to the institution. This harm may be caused in a number of ways.

First, because there is great latitude afforded to development officers in soliciting gifts, a development officer might be tempted to enter into an agreement with a donor to create a specific program for which the university has no need or want. While accepting such a donation might help the institution reach its capital campaign or yearly fund-raising goals, it may move the college or university in an academic direction that its leaders had not intended. The task of crafting academic policy is best left to provosts, deans, and department chairs, not donors and development officers.

A second possible way in which the institutional client might be harmed is through inappropriate behavior on the part of the fund raiser. Because the role of fund raiser is one of boundary spanner, the development officer represents the organization to individuals who are outside of the organization and in the community. Because the development officer is the embodiment of the university, his or her actions will reflect directly on the institution's reputation. This is another instance where a fund raiser may cause harm to an institutional client.

Fund raisers must also protect the individuals who provide funds to their institutions. In order to know as much as possible about potential donors, college and university development offices conduct research into the financial and personal backgrounds of these individual donors. Much of this information could be potentially damaging if revealed to the general public. Some donors also desire some degree of confidentiality about their gifts. Development officers are responsible for ensuring that this information is protected.

One area of fund raising that poses a potential threat to the welfare of the donor client is planned giving. Planned 
gifts are structured toward the later years of a prospect's life and in many cases provide income for that person until the time of his or her death. This type of gift can be potentially damaging to the donor if the amount of income guaranteed by the institution is not enough for the donor to meet expenses. Additionally, with uncertain health, a problem in elderly donors, those individuals who tie up a large percentage of their capital in a structured gift may run into problems taking care of themselves when unforeseen health problems arise.

Because of the potential financial and reputational damage that may be inflicted on a potential donor through a development officer's behavior, fund raisers do bear a responsibility for the welfare of their donor clients.

\section{Autonomy}

One of the privileges granted to members of a profession is autonomy. This autonomy from external review is granted by society with the expectation that members of a profession will police their own behavior. A failure to regulate misconduct results in a loss of trust of the profession and its members by the public. ${ }^{25}$ Consequently, the profession's autonomy is threatened. By sanctioning those who engage in misconduct, a profession reassures the public that its faith in the profession is justified.

Professional fund raisers who are employed in higher education do enjoy some degree of autonomy in the performance of their duties. While most development officers are accountable to someone in the university hierarchy, there is a great deal of latitude in the methods by which individuals are solicited for gifts. Most development officers devise their own strategies for cultivating and soliciting individual prospects.

Additionally, they are responsible for determining the best time to ask for a gift based upon a relationship developed with the prospect.

\section{Interrelationship Among Core Traits}

The professional traits of mastery of knowledge, ideal of service, and autonomy are interrelated. If individuals in a profession are granted the privilege of operating autonomously, the public expects that the profession will regulate its members' behaviors. Specifically, to ensure that the profession's members adhere to the ideal of service to its clients, the profession must sanction those behaviors that are not in the best interest of clients. Additionally, those members of the profession are expected to have mastered the knowledge base that will allow them to make decisions that will not cause harm to their clients.

For the fund-raising profession, this interrelationship is reflected in the formulation of how individuals progress from entry-level fund-raising positions to more senior positions. Individuals who are involved in major gifts work have typically been involved in the profession for a number of years. They may have progressed from asking for smaller gifts, which have little potential for doing harm to the donor, to soliciting donors for large structured gifts that have important tax implications. While the profession's formal knowledge base may be lacking, there is an extended period of on-the-job training as individuals move into different areas of fund raising with additional responsibility.

In the course of this progression, individuals are granted more autonomy as 
the solicitations become more intricate and the potential for harm to the individual and the institution increases. With this increased exposure to making decisions that could have serious negative consequences, the fund raiser must be even more strongly committed to the ideal of service to both the donor and institutional client. The profession must also ensure that as more autonomy is granted, individual fund-raiser behavior is regulated.

\section{Professional Self-regulation}

The notion of ideal of service to both donor and institutional clients by fund raisers is evidenced in their codes of conduct and the Donor Bill of Rights. The code of ethics protects the interests of both donor and institutional clients. In a discussion of the regulation of the fundraising profession in 1985 at the Greenbrier II conference, the decision was made not to develop a body responsible for imposing sanctions on those individuals who have violated the code of ethics. However, at this gathering, it was decided that the statement of ethics should be promoted and guidelines, along with illustrative cases, should be developed for each area outlined in the Code of Ethics and Donor Bill of Rights.

Without a sanctioning body, or a formal way of regulating the actions of fund raisers, the profession would necessarily rely upon informal selfregulation of its membership. ${ }^{26}$

Professions ensure that members adhere to the ideal of service through the use of formal and informal social control mechanisms. ${ }^{27}$ Goode suggests that these rules are taught to new members of a profession through the socialization process. These social control mechanisms define what behaviors by members of a profession are appropriate and inappropriate. ${ }^{28}$

\section{Formal Social Control Mechanisms}

One marker of the degree of professionalism an occupation has attained is the existence of a code of conduct. ${ }^{29}$ Published codes of ethics by which professionals are expected to abide are an example of a formal social control mechanism. These codes assist a profession in attaining professional autonomy and self-regulation. ${ }^{30}$ They also serve as a measuring stick against which members of a profession may judge the relative impropriety of certain demands. ${ }^{31}$ “Through its ethical code, a profession's commitment to the social welfare becomes a matter of public record, thereby insuring for itself the continued confidence of the community. ${ }^{, 32}$

As discussed previously, both of the major professional organizations to which college and university fund raisers belong have explicitly stated codes of ethics for their members. However, Kelly found that less than half (44\%) of the organizations represented in AFP had policies regarding the acquisition of gifts, and 50 percent count on professional fund raisers to abide by a code of professional ethics when receiving gifts or to judge gifts on an individual basis. ${ }^{33}$ Lombardo found that only four of the 12 charitable institutions she studied had formal guidelines to deal with cases of conflict of interest between fund raisers and donors. ${ }^{34}$ In his study of fund raisers who are members of CASE, Carbone found that 30 percent of them were unsure if their national organization played a role in setting standards and protecting the right to practice. Additionally, he found that 


\begin{abstract}
" $28 \%$ are unsure if this function is important and $10 \%$ thought it was unimportant for the organization to do this." 35
\end{abstract}

\section{Informal Social Control Mechanisms}

In the absence of formal social control mechanisms, fund raisers must rely upon informal mechanisms to ensure that members of the profession are conforming to what are considered appropriate behaviors. Carlin and Freidson both found that informal rules are more important social control mechanisms than formal controls. ${ }^{36}$

Norms are one mechanism through which professions self-regulate using informal social controls. Norms are shared beliefs about how an individual should act in a particular situation. ${ }^{37}$ Merton suggests that norms function as mechanisms of social control because they consist of prescribed and proscribed patterns of behavior. ${ }^{38}$ This concept is derived from Durkheim's statement that the natural human condition is unregulated passion, whereas conforming requires social regulation. ${ }^{39}$ Without a normative structure, individuals in the profession would be free to act as they saw fit, with individuals deciding for themselves what behaviors constituted appropriate and inappropriate behavior. Additionally, "norms assure that professional choices adhere to the ideal of service." ${ }^{40}$ By selfregulating, a profession communicates to its members the necessity of stewarding the welfare of its clients.

The degree of moral outrage that accompanies the violation of a norm indicates the social significance of the norm. ${ }^{41}$ Norm-violating behaviors that individuals view as highly inappropriate carry a higher penalty and increased social significance as compared to those behaviors which are not as inappropriate.

Morris writes that "norms are generally accepted, sanctioned prescriptions for or prohibitions against, others' behavior, belief or feeling, i.e. what others ought to do, believe, feel-or else." ${ }^{42}$ He goes on to state that violation of accepted norms always involve sanctions. Norms serve as a guide to how fund raisers perform the roles associated with the fund-raising profession. They represent the "collective conscience" of the profession and dictate what is appropriate and inappropriate behavior for its members. ${ }^{43}$ Violation of these norms by development officers may result in sanctioning by peers, institutions, and the government.

\section{Fund-raising Norms}

In a study of CASE fund raisers, Caboni found three inviolable and six admonitory norms. $^{44}$

\section{Inviolable Norms}

The violation of inviolable norms is perceived as being the most egregious and warranting the most severe sanctions. ${ }^{45}$ The three violations of these norms, in alphabetical order, are: exploitation of institutional resources, institutional disregard, and misappropriation of gifts. Each of these is described below.

\section{Exploitation of institutional resources}

This normative pattern proscribes behaviors by fund raisers that take advantage of an institution's funds, or other things of value that the institution possesses (including offers of admission), for personal gain. Three examples of prohibitive behavior are: a fund raiser makes personal charges on an institutional credit card and submits them as business 
expenses; a fund raiser agrees to get a student admitted to the institution if a gift is made; and a fund raiser pads a call report with visits he or she did not make.

\section{Institutional disregard}

The normative pattern of institutional disregard proscribes behaviors by fund raisers that would damage the reputation of the fund raiser's employing institution. As discussed earlier, the institution for which a fund raiser works is a client of the fund raiser. Violating this norm puts at risk the welfare of the fund raiser's institutional client. Four examples of prohibited behaviors are: a fund raiser speaks poorly about the institution to a prospect; a fund raiser provides a copy of a prospect list to another institution; a fund raiser tells someone outside of the institution private information about a donor; and a fund raiser gets drunk at an official institution function.

\section{Misappropriation of gifts}

The inviolable norm regarding misappropriation of gifts includes transgressions by fund raisers in which donations are used for purposes that were not intended by the donor. Violation of this normative pattern could cause damage both to the donor-client relationship (by misusing the funds given by the individual) and the institutional client (if the donor relationship is compromised because the donation was not used for its intended purpose, the donor might never make another gift to the college). Three examples of prohibited behaviors are: a fund raiser allows the income from a restricted scholarship fund to be used for a purpose other than scholarships; a fund raiser uses restricted funds to support an institution's operating budget; and a fund raiser allows a donor's gift to be used for something other than for what it was intended.

\section{Admonitory Fund-Raising Norms}

Caboni also found six admonitory norms in his study of CASE fund raisers. ${ }^{46}$ The violation of admonitory norms is perceived as being inappropriate, but not requiring the severity of sanctioning reserved for the violation of inviolable norms. ${ }^{47}$ The six violations of admonitory norms, in alphabetical order, are: commission-based compensation, dishonest solicitation, donor manipulation, exaggeration of professional experience, institutional mission abandonment, and unreasonable enforcement of pledges. Each of these is explained below.

\section{Commission-based compensation}

The admonitory norm regarding commission-based compensation includes transgressions by fund raisers in which an individual's salary is paid in part or in full as a percentage of the dollar total raised by that fund raiser. Violation of this normative pattern is in direct conflict with the code of ethical standards for fund raisers. The purpose of discouraging these types of compensation packages is to ensure that an individual raising funds for an institution does not take advantage of a donor for financial gain (e.g., pushing a donor to make a gift that will do harm to the individual's financial standing because a large gift will result in a large commission). An additional argument against commission-based compensation is that placing pressure on a donor to make a gift solely for the purposes of meeting a dollar goal may jeopardize the receipt of a larger gift from the donor in the future. 
Two prohibited behaviors are: a fund raiser works on a commission basis; and a fund raiser agrees to base a part of his or her annual salary as a percentage of total dollars raised.

\section{Dishonest solicitation}

The normative pattern of dishonest solicitation proscribes behaviors by fund raisers that involve untruthfulness while a fund raiser asks a prospect for a gift. By violating this norm, a fund raiser takes advantage of the autonomy granted to development officers in the conduct of their professional duties. By lying or bending the truth, the fund raiser puts at risk the relationship with the potential donor. Four examples of prohibited behaviors are: a fund raiser knows that a donor received double credit for a gift, but does not tell anyone; a fund raiser tells a donor their gift will solve a particular institutional problem when, in reality, the gift will not solve the problem; a fund raiser makes a mistake and blames an administrative assistant; and a fund raiser intentionally uses confusing language when describing the details of a planned gift to a donor.

\section{Donor manipulation}

The normative factor dealing with donor manipulation involves a fund raiser's handling of delicate relationships with a donor. Individuals who have lost or are losing the capacity to make sound decisions for themselves should not be solicited for gifts. By exploiting these individuals, a fund raiser is potentially causing harm to the donor client. Donor manipulation consists of two prohibited behaviors: a fund raiser attempts to solicit a planned gift from a prospect, even though it is not in the prospect's best interest and a fund raiser asks a prospect whose mental faculties are in question to make a gift because it would be of benefit to the institution.

\section{Exaggeration of professional experience}

The normative array with respect to exaggeration of professional experience centers on fund raisers who embellish the fund-raising work they have done either at a previous institution or for their current employer. Four disapproved behaviors are: a fund raiser inflates his or her dollar raised totals in a previous position; a fund raiser exaggerates his or her professional experience; a fund raiser takes credit for a gift brought in by another development officer; and a fund raiser takes credit for another staff member's idea.

\section{Institutional mission abandonment}

The behaviors associated with institutional mission abandonment are focussed on fund raisers attracting gifts for activities and programs for which the institution has no need. Because fund raisers are not involved directly in the academic enterprise of the institution, they should not create or change academic programs according to the whim of donors. Doing so infringes upon the institution's autonomy to make programmatic decisions based upon the best interest of enrolled students. Three examples of disapproved behaviors are: a fund raiser allows a donor to make a gift that creates a program the institution does not need or want; a fund raiser agrees to accept a gift from a donor, the use of which is too narrowly defined to be of use to the institution; and a fund raiser accepts a gift because it adds to fund-raising totals, even though the institution has no need for the program the gift will fund. 


\section{Unreasonable enforcement of pledges}

The admonitory norm that proscribes the unreasonable enforcement of pledges is the final admonitory norm that emerged from the data. This norm prohibits fund raisers from taking legal action against a donor or their families in the pursuit of gifts promised to an institution, or from refusing to return a gift made by a donor who is unhappy with how the gift is being used. While a pledge may be considered a legally binding document, this norm advises fund raisers (and in turn their institutions) from pursuing legal action against donors and their families. Two behaviors that violate this norm are: a fund raiser takes a deceased donor's family to court to force them to fulfill the donor's pledge because the gift would benefit the institution, and a fund raiser refuses to return a gift to a donor who is upset with how the funds are being used and has asked for the gift to be returned.

\section{Discussion}

From the nine norms listed above, the following four conclusions may be drawn. First, moral boundaries for the practice of fund raising in colleges and universities do exist. Braxton and Bayer suggest that normative patterns establish moral boundaries for members of a profession. ${ }^{48}$ These normative patterns espoused by members of the fund-raising profession establish boundaries that should not be crossed in the conduct of their duties. These boundaries restrict the autonomy they have in how they solicit donors (unreasonable enforcement of pledges and dishonest solicitation), how they represent their institutions (institutional disregard), how they steward university funds (exploitation of institutional resources and misappropriation of gifts), how they persuade prospects to make donations (commission-based compensation and donor manipulation), how they decide for what individuals should be solicited (institutional mission abandonment), and how they represent themselves professionally (exaggeration of professional experience).

Second, because fund raisers within higher education presumably use norms to self-regulate, it is a marker of additional professionalism for the fund-raising profession. College and university development officers enjoy latitude in the approaches that they use to solicit individuals for gifts to their institutions. This professional autonomy is granted to a profession with the expectation that that profession's members will regulate their own behavior and the behavior of their colleagues. ${ }^{49}$ One way a profession ensures that its members behave appropriately is through the use of informal social control mechanisms. Norms are one device used by members of a profession to selfregulate. Because a normative structure does exist for college and university fund raisers, it suggests that fund raising is maturing as a profession.

Third, the identified normative patterns protect the welfare of both institutional clients and donor clients. Goode suggests that members of a profession must base their individual decisions on what will serve the needs and protect the welfare of their clients. ${ }^{50}$ The inviolable and admonitory norms that emerged from this study serve to protect the interests of both sets of clients for fund-raising professionals. However, the institutional client receives more protection, because the inviolable norms tend not to prohibit behaviors that might cause harm to the fund raiser's donor client. The donor 
client is protected through five of the six admonitory norms.

The welfare of donor clients is protected by one inviolable norm (misappropriation of gifts) and five admonitory norms (commission-based compensation, dishonest solicitation, donor manipulation, exaggeration of professional experience, and unreasonable enforcement of pledges). Institutional clients are protected by three inviolable norms (exploitation of institutional resources, institutional disregard, and misappropriation of gifts) and one admonitory norm (exaggeration of professional experience).

While both individual donor clients and institutional clients are protected by these norms, the most severe sanctions are reserved for those transgressions that pose the threat of harm to an institutional client. All three of the inviolable norms serve to protect institutional clients. Only one protects the welfare of donor clients. Of the six admonitory norms, which require less severe sanctions than inviolable norms, five protect the welfare of donors. Only one admonitory norm proscribes behaviors that could cause harm to the fund raiser's institution.

The norms show that the protection of institutional clients occurs primarily through inviolable normative patterns and the protection of donor clients occurs primarily through admonitory normative patterns. A possible explanation for this involves the pressure on development officers to meet annual dollar goals. The easiest and most common way to evaluate the performance of fund raisers is an examination of total dollars raised compared with previous year totals. As a result, a fund raiser's primary concern is frequently the total amount of money he or she has raised. If a fund raiser were to violate any of the three inviolable norms, his or her chances of getting a gift would not increase. However, if a fund raiser violates admonitory norms, he or she may have an increased opportunity to receive a gift from a donor, even though the gift may have come through what some would perceive as inappropriate fund-raising behaviors.

Finally, the normative patterns that emerged in this study parallel the formal codes of ethics for CASE and AFP. The norms that protect the donor are codified in the donor bill of rights adopted by CASE. However, the norms that prohibit transgressions against the fund raiser's institution are represented in the CASE Statement of Ethics only in generalities. AFP's code of ethical principles is much more thorough in its treatment of inappropriate behaviors. Each of the three inviolable and five of the admonitory norms appear in the code. The admonitory norm against institutional mission abandonment does not appear in any of the discussed codes. This is an example of neglect on the part of the profession to incorporate what are informal norms into the written ethical codes.

This reflects the focus (especially by CASE) on the welfare of the donor. However, CASE's statement of ethics is more broadly constructed than that of AFP because many different functional areas are represented within the organization. Members of CASE may be responsible for other institutional advancement areas including public relations, publications, and alumni relations. AFP's membership, in contrast to CASE's, comprises primarily individuals whose sole responsibility is fund raising. 
This narrow focus allows for a more detailed description of fund-raising behaviors that are proscribed by the profession in its ethical code.

\section{Practical Implications}

The normative patterns discussed above suggest a number of implications for those individuals engaged in professional fund-raising activities, for those involved in the preparation of future development officers, and for institutional policy makers who are responsible for institutional advancement or development operations. Six implications for practice are described below.

First, fund raising is progressing to professionalization. Carbone suggests that fund raising is an emerging profession, possessing some of the markers of a full profession; it is "an emerging professionan occupation that has moved steadily along the professional continuum; a profession with the potential to attain greater professional stature." 51 This study demonstrates that the fund-raising profession possesses another marker of a profession not previously identified.

Because fund raisers espouse the normative patterns that protect both donor and institutional clients, the existence of a concern for client welfare does exist within the profession.

Second, the ethical code for CASE should have more specific language added to describe fund raiser responsibility to the institutional client. The focus of the Donor Bill of Rights is obviously on the welfare of the donor client. Specific responsibilities are not delineated for the institutional client. However, it is interesting to note that although an entire document exists outlining the rights of a donor, the normative patterns prohibiting behaviors that might cause harm to a donor are almost exclusively in the admonitory category. Those norms that proscribe behaviors that place the institution in jeopardy are primarily inviolable. This is not surprising; after all, the institution pays the fund raiser's salary.

Third, those college and university administrators might use the College Fund Raising Behaviors Instrument as a tool to evaluate the development staff within their institutions. CASE and AFP could also develop a kit for fund-raising managers that would include the instrument and the national average for each fund-raising norm. By administering the instrument to those individuals involved in the solicitation of gifts and comparing the results for the institution with the results reported in this study, individuals who are responsible for fund raising may begin a dialogue with staff fund raisers about similarities and differences between the organization's results and the perception of other fund raisers. By stating explicitly those behaviors that colleagues consider inappropriate, those individuals who are not aware of informal norms will be made aware of them.

Fourth, with the recent increase in the number of courses and degree programs in nonprofit management and institutional advancement, these identified normative patterns should be taught to individuals who plan on entering the profession. Additionally, they should be included in sessions presented at various professional conferences. Goode suggested that norms are inculcated through the process of socialization. ${ }^{52}$ One period of intense socialization is graduate school. If students in these programs are made aware of the formal codes of ethics and well as the informal codes, perhaps variation in espousal of these norms will be reduced. 
Fifth, CASE could add the presentation of these norms to those newcomers who attend the national assembly and district conferences each year. As part of the socialization process, formally introducing newcomers to the norms presented above would give concrete boundaries for what fund raisers consider inappropriate behaviors. Additionally, discussions could be structured around each norm so that newcomers might more fully understand the responsibilities placed upon fund raisers for the welfare of both donors and institutions.

A final implication for the practice of fund raising involves the need to establish mentorships for those individuals who are entering the profession. By developing relationships between neophyte fund raisers and those who have been practicing members of the profession for many years, the profession will decrease the chance that those behaviors that are perceived as inappropriate by those in the profession will be adopted by those who are new. Mentors could be assigned as individuals are hired into an organization.

Professional organizations may also engage in this practice.

\section{References}

1. A. M. Carr-Saunders and P. A. Wilson (1933), The Professions, Clarendon Press, Oxford.

2. E. Greenwood (1957), "Attributes of a profession," Social Work, 2, pp. 44-55.

3. Ibid., p.46.

4. T. Parsons (1939), "The professions and social structure," Social Forces, 17, pp. 457-67, quote p.463.

5. T. J. Johnson (1972), Professions and Power, Macmillan, London.

6. E. Freidson (1970), Professional Dominance, Aldine, Chicago.

7. J. L. Berlant (1975), Profession and Monopoly, University of California Press, Berkeley; M. S. Larson (1977), The Rise of Professionalism, University of California Press, Berkeley.
8. E. Freidson (1975), Doctoring Together: A Study of Professional Social Control, Elsevier, New York.

9. A. Abbott (1988), The System of Professions, University of Chicago Press, Chicago.

10. Ibid., p. 59.

11. Ibid., p. 102

12. S. Brint (1994), The Changing Roles of Professionals in Politics and Public Life, Princeton University Press, Princeton, NJ.

13. W. J. Goode (1969), "The theoretical limits of professionalization," in Amati Etzoni (Ed.), The Semi-professions and their Organization, New York: Free Press, pp. 266-313.

14. R. F. Carbone (1989), Fund Raising as a Profession, Monograph No. 3, University of Maryland, Clearinghouse for Research on Fund Raising, College Park.

15. Ibid.

16. R. F. Carbone (1989), An Agenda for Research on Fund Raising, University of Maryland, Clearinghouse for Research on Fund Raising, College Park.

17. A. W. Rowland (1983), Research in Institutional Advancement: A Selected, Annotated Compendium of Doctoral Dissertations, Council for the

Advancement and Support of Education, Washington, DC, p.iii.

18. K. S. Kelly (1991), Fund Raising and Public Relations: A Critical Analysis, Lawrence Erlbaum Associates, Hillsdale, NJ, p.114; Rowland (1983), Research in Institutional Advancement op. cit.; A. W. Rowland (1986), Research in Institutional Advancement: Addendum, Council for the Advancement and Support of Education, Washington, DC.

19. B. E. Brittingham and T. R. Pezzullo (1990), The Campus Green: Fund Raising in Higher Education, ERIC Clearinghouse on Higher Education, Washington, DC.

20. K. E. Burke (1988), "Institutional image and alumni giving," unpublished doctoral dissertation, University of Maryland, College Park.

21. R. L. Payton (1987), "American values and private philanthropy; Philanthropic values," in K. W. Thompson (Ed.), Philanthropy: Private Means, Public Ends, University Press of America, Lanham, MD, pp. 3-46, 123-36, quote p.133.

22. Brint (1994), The Changing Roles of Professionals in Politics and Public Life, op. cit.

23. Goode (1969), "The theoretical limits of professionalization,” op. cit.

24. H. A. Rosso (1996), Rosso on Fund Raising: Lessons from a Master's Lifetime Experience, Jossey-Bass, San Francisco.

25. Goode (1969), "The theoretical limits of professionalization," op. cit.

26. Ibid. 
27. J. M. Braxton (1986), "The normative structure of science: Social control in the academic profession," in J. C. Smart (Ed.), Higher Education: Handbook of Theory and Research, vol. 2., Agathon Press, New York, pp. 309-57; J. M. Braxton, A. E. Bayer, and M. J. Finkelstein (1992), "Teaching performance norms in academia," Research in Higher Education, 33, October, pp. 553-69; R. Bucher and A. Strauss (1961), "Professions in process," American Journal of Sociology, 66, November, pp. 325-34; W. J. Goode (1957), "Community within a community: The professions," American Sociological Review, 22, pp. 194-200.

28. Goode (1957), "Community within a community," op. cit.

29. Carr-Saunders and Wilson (1933), The Professions, op. cit.; B. Barber (1962), Science and the Social Order, Collier, New York; G. Harries-Jenkins (1970), "Professionals in organizations," in J. A. Jackson (Ed.), Professions and Professionalization, Cambridge University Press, New York, pp. 53-107; A. Abbott (1983), "Professional ethics," American Journal of Sociology, 88, 5, pp. 855-85.

30. J. R. Cohen and L. W. Pant (1991), "Beyond bean counting: Establishing high ethical standards in the accounting profession," Journal of Business Ethics, 10, pp. 45-6.

31. M. S. Frankel (1989), "Professional codes: Why, how and with what impact?" Journal of Business Ethics, 8, pp. 109-115.

32. E. Greenwood (1966), "The elements of professionalism," in H. M. Vollmer and D. L. Mills (Eds.), Professionalization, Prentice-Hall, Englewood Cliffs, NJ, pp. 9-19, quote p.14.

33. K. S. Kelly (1995), "The fund-raising behavior of U.S. charitable organizations," Journal of Public Relations Research, 7, 2, pp. 111-37.

34. B. J. Lombardo (1991), "Conflicts of interest between nonprofits and corporate donors," in D. F. Burlingame and L. J. Hulse (Eds.), Taking Fundraising Seriously: Advancing the Profession and Practice of Raising Money, Jossey-Bass, San Francisco, pp. 83-99.

35. Carbone (1989), Fund Raising as a Profession, op. cit. p. 32.
36. J. Carlin (1966), Lazeyer's Ethics, Sage, New York; Freidson (1975), Doctoring Together.

37. R. K. Merton (1968), Social Theory and Social Structure, Free Press, New York; R. K. Merton (1973), The Sociology of Science: Theoretical and Empirical Investigations, University of Chicago Press, Chicago.

38. R. K. Merton (1957), "Priorities in scientific discovery," American Sociological Reviewe, 2, pp. 63559; Merton (1968), Social Theory and Social Structure.

39. E. Durkheim (1951), Suicide, trans. John H. Saulding and George Simpson, Free Press, New York.

40. J. M. Braxton and A. E. Bayer (1999), Faculty Misconduct in Collegiate Teaching, Johns Hopkins University Press, Baltimore, MD, p. 4.

41. E. Durkheim (1995), The Elementary Forms of Religious Life, trans. K. E. Fields, Free Press, New York.

42. R. T. Morris (1956), "A typology of norms," American Sociological Review, 21, 5, pp. 610-13, quote p.610.

43. Durkheim (1951), Suicide, op. cit.

44. T. C. Caboni (2001), "The normative structure of college and university fund raising," Unpublished doctoral dissertation, Vanderbilt University, Nashville, TN.

45. Braxton and Bayer (1999), Faculty Misconduct in Collegiate Teaching, op. cit.

46. Caboni (2001), "The normative structure of college and university fund raising," op. cit.

47. Braxton and Bayer (1999), Faculty Misconduct in Collegiate Teaching, op. cit.

48. Ibid.

49. W. J. Goode (1969), "The theoretical limits of professionalization.” op. cit.

50. Ibid.

51. Carbone (1989), Fund Raising as a Profession, op. cit. p.46.

52. Goode (1957), "Community within a community," op. cit.

\section{Practitioner's Perspective}

Is fund raising a "true profession"? In this article the author compares fund raising as a profession against standard characteristics that sociologists have identified to determine whether a particular occupation is a "profession" and concludes that yes, fund raising is "an emerging profession." Moreover it is "an occupation that has moved steadily along the professional continuum; a profession with the potential to attain greater professional stature." 
In taking a comprehensive look at the characteristics that true professions possess and comparing the fund-raising profession against those characteristics, the article is both informative and timely. Our institutional fund-raising programs are under growing pressure to increase the private gift support as our state budgets continue to shrink and our endowments continue to slide in the current economy. The author identifies four key characteristics of a profession: (1) an intensive period of training and socialization, (2) the possession of a systematic body of theory, (3) the formation of professional associations, and (4) the existence of a code of conduct.

The profession of fund raising meets each of these criteria, albeit in varying degrees. The strength of this article is the road map the author has prepared for us to study as we continue in our drive for increased professionalism. Two areas of particular interest are his discussion of formal and informal training programs and a growing systematic body of theory. I believe there is a strong connection between these two areas. As fund raisers we serve our institutions in positions of privilege. The author refers to this role as one of "boundary spanner"-representing both the institution and the donor. To best serve both the institution and the donor our growing skills as fund raisers should be based on solid research that in turn leads to best practices. We need to clearly understand effective and appropriate fundraising techniques for our work with donors. We also need to be fully integrated into our institutions in order to represent true academic priorities and goals. As our fund-raising programs continue to grow in size and scope, we owe it to our institutions to become more sophisticated, professional, and effective.

As fund-raising managers, we are responsible for guiding the progress of our fund-raising staff from entry level to more senior positions. This has been largely an informal process, but there are increased signs of more formal career paths being established, especially at large institutions. There are increasing sources of educational opportunities available for training and development of our fundraising staff, through CASE, AFP, and other organizations. The better we can articulate appropriate skills, experience, and career steps necessary for fund raisers, the closer we will be in our drive toward professionalism.

As a profession, fund raising has made significant progress over the past 20 years; however, there is much we can continue to do to ensure we are meeting our responsibilities to both our institutions and our donors. With his solid review and analysis of our "emerging" profession of fund raising, in comparison with other, "true" professions, the author has given us several key guideposts as we continue our journey. 